\title{
Kajian Penggunaan Material Pasir Sumpur Kudus untuk Meningkatkan Kinerja Lapisan Pondasi Atas Agregat Kelas A
}

\author{
Enita Suardi ${ }^{1}$ Lusyana ${ }^{2)}$ Yelvi ${ }^{3)}$ \\ 1)Staf pengajar Politeknik Negeri Padang, email : enitasuardi@yahoo.co.id \\ 2) Staf pengajar Politeknik Negeri Padang, email : lusyana_poli@yahoo.com \\ 3) Staf pengajar Politeknik Negeri Jakarta, email :yelvi_ch@yahoo.com
}

\begin{abstract}
Abstrak
Permasalahan yang biasa terjadi pada proses pembuatan lapis pondasi perkerasan jalan agregat kelas $\mathrm{A}$ adalah sulitnya memenuhi kebutuhan agregat halus yang memenuhi persyaratan gradasi. Penelitian ini dilakukan mengkaji bagaimana membuat suatu campuran agregat kelas $\mathrm{A}$ yang sesuai dengan gradasi dan juga sesuai dengan ketersedian material yang ada di daerah tersebut. Pemanfaatan pasir gunung daerah Sumpur Kudus ini sebagai subtitusi agregat halus, diharapkan dapat menyelesaikan dua permasalahan sekaligus yaitu memperoleh lapisan pondasi agregat kelas A yang mempunyai nilai CBR yang memenuhi persyaratan sekaligus pemanfataan material lokal yang selama ini hanya bertumpuk dan terbuang hasil dari longsoran yang sering terjadi.

Metode yang digunakan adalah metode eksperimen skala laboratorium . Campuran agregat kelas A yang digunakan adalah $64,5 \%$ agregat kasar dan $35,5 \%$ agregat halus yang terdiri dari campuran pasir sungai dan pasir Sumpur Kudus. Pengujian yang dilakukan adalah pengujian sifat fisisdan pemadatan terhadap pasir Sumpur Kudus serta pengujian California Bearing Capacity (CBR) terhadap agregat kelas A.

Hasil penelitian memperlihatkan dengan digunakannya pasir Sumpur Kudus sebagai pengganti agregat halus pada campuran lapis pondasi agregat kelas A, nilai CBR laboratorium meningkat 5,62\% yaitu dari $40,58 \%$ menjadi $46,2 \%$. Tapi nilai CBR laboratorium yang diperoleh ini belum memenuhi nilai CBR yang disyaratkan untuk agregar kelas A yaitu nilai minimal $90 \%$.
\end{abstract}

Kata kunci: lapis pondasi perkerasan jalan, agregat kelas $\mathrm{A}$, nilai $C B R$ 


\section{Pendahuluan}

Salah satu lapisan dari struktur perkerasan jalan yang ikut mendukung beban adalah lapis pondasi atas (base course). Lapis pondasi atas yang berasal dari campuran agregat berbutir disebut lapis pondasi agregat, yang sangat umum digunakan di Indonesia terutama pada daerah-daerah yang mempunyai deposit material batu kali/batu sungai. Salah satu campuran lapis pondasi agregat yang banyak digunakan adalah Lapis Pondasi Agregat Kelas A. Persyaratan agregat halus pada material agregat kelas $A$ ini berasal dari partikel pasir atau batu pecah halus yang harus bebas dari bahan organik dan gumpalan lempung.

Permasalahan yang biasa terjadi pada proses pembuatan Lapis Pondasi Agregat Kelas A adalah sulitnya memenuhi kebutuhan agregat halus (lolos saringan 4,75 $\mathrm{mm}$ ) yang memenuhi persyaratan gradasi. Hal ini disebabkan sifat material quarry setempat. Contohnya yang berasal dari Kabupaten Sijunjung, material batu sungai pada semua lokasi quarry memiliki perkiraan nilai abrasi berkisar antara 12-18\% (Dinas PU Kabupaten Sijunjung).

Untuk menutupi kekurangan agregat halus tersebut, seringkali lapis pondasi agregat kelas A dicampur dengan pasir sungai guna memenuhi persyaratan gradasi dalam spesifikasi. Namun karena pasir sungai memiliki bentuk butir yang bulat sehingga tidak memiliki gaya kunci mengunci antar agregat (aggregate interlocking) dan proses pemadatan lapis pondasi agregat kelas A yang dicampur dengan material pasir sungai cenderung sulit untuk dilakukan. Untuk mengatasi hal tersebut, penambahan pasir sungai selalu diiringi dengan penambahan tanah lempung (clay) dengan jumlah maksimal $5 \%$ terhadap jumlah total campuran. Clay dapat membantu memberikan ikatan pada material lapis pondasi agregat kelas $\mathrm{A}$ yang menggunakan pasir sungai tersebut, sehingga lebih mudah dipadatkan dan penambahan clay pada lapis pondasi agregat kelas A menyebabkan campuran tersebut memiliki nilai plastisitas (PI).

Mayoritas jenis tanah dasar badan jalan yang ada di Kabupaten Sijunjung adalah tanah lempung kepasiran yang bersifat kohesif dan memiliki nilai plastisitas tinggi (Dinas PU Sijunjung, 2008). Penggunaan Lapis Pondasi Agregat Kelas A dengan tambahan pasir sungai dan clay menimbulkan masalah yang lebih serius. Seringkali pada saat pemadatan Lapis Pondasi Agregat Kelas A dengan vibratory roller (alat pemadat getar) menyebabkan naiknya air (air dari tanah dasar atau air dari campuran Lapis Pondasi Agregat Kelas A) yang membawa lempung dari tanah dasar masuk ke lapisan pondasi atas, menyebabkan persentase clay pada agregat kelas A lebih dari $5 \%$ (over clay). Kondisi Lapis Pondasi Agregat Kelas A yang bersifat over clay ini menyebabkan kepadatan maksimum campuran dan CBR lapangan yang diperoleh tidak memenuhi persyaratan.

Penelitian ini akan memanfaatkan tanah pasir gunung Sumpur Kudus yang selalu mengalami kelongsoran untuk dijadikan pengganti agregat halus (pasir dan clay) pada lapisan pondasi agregat kelas A. Diharapkan nilai kepadatan dan CBR yang diperoleh memenuhi persyaratan dan lapisan pondasi 
agregat kelas $A$ ini tidak mengalami over clay lagi.

\section{Tujuan Penelitian}

1. Melakukan pengkajian parameterparameter sifat fisis pasir Sumpur Kudus yang akan digunakan sebagai pengganti agregat kelas $A$ perkerasan jalan

2. Melakukan pengkajian terhadap perilaku sifat mekanis yaitu nilai CBR agregat klas A yang menggunakan pasir Sumpur Kudus sebagai sebagai pengganti material pasir sungai dan clay yang selama ini digunakan

3. Memahami kinerja pasir Sumpur Kudus yang digunakan sabagai agregat klas $A$ lapisan base perkerasan jalan.

\section{Tinjauan Pustaka}

Lapis Pondasi Agregat Kelas A

Terdapat tiga kelas yang berbeda dari Lapis Pondasi Agregat yang menggunakan batu pecah yaitu Kelas A, Kelas B dan Kelas C. Lapis Pondasi Atas harus terdiri dari Agregat Kelas A atau Kelas B, sedangkan Lapis Pondasi Bawah harus terdiri dari Agregat Kelas C. Campuran yang bisa digunakan sebagai lapis pondasi atas harus memenuhi persyaratan $\mathrm{CBR} \geq 50 \%$, PI $\leq 4$ $\%$.

Campuran agregat kelas A merupakan salah satu jenis material yang digunakan sebagai material lapis pondasi atas pada suatu perkerasan jalan dengan persyaratn CBR min 90\%. Agregat kasar yang digunakan pada campuran Kelas A (tertahan pada ayakan 4,75 $\mathrm{mm}$ ) harus terdiri dari partikel yang keras dan awet dan berasal dari batu kali yang $100 \%$ mempunyai paling sedikit dua bidang pecah. Sedangkan agregat halus yang digunakan (lolos ayakan 4,75 mm) harus terdiri dari partikel pasir atau batu pecah halus. Tapi karena keterbatasan sumber daya agregat halus dari hasil abu batu, seringkali di lapangan digunakan pasir sebagai bahan subtitusi agregat halus. Pasir merupakan salah satu agregat alam yang diperlukan untuk masing-masing lapisan tersebut. Untuk lapisan pondasi atas dan pondasi bawah penggunaan pasir akan memberikan kepadatan yang tinggi, sehinggga lapisan mempunyai nilai daya dukung yang cukup baik. Tetapi penggunaan pasir yang yang berlebihan adalah susah dipadatkan terutama penggunaan pasir sungai yang memiliki bentuk butiran bulat (rounded) yang mudah bergerak bila ada beban diatasnya (Ismanto, B, 2001)

Penggunaan Pasir sebagai material jalan

Penelitian yang menggunakan pasir sebagai material campuran lapis pondasi agregat telah banyak diteliti. Salah satu adalah penelitian tentang penggunaan pasir tailing yang merupakan limbah hasil pengolahan biji emas yang depositnya sangat banyak di daerah Papua. Pada penelitian yang dilakukan oleh Edie Dunaedie dan $R$. Anwar Yamin dari Pusat Penelitian dan Pengembangan Jalan Dan Jembatan pada tahun 2008 ini, prosentase tailing untuk Campuran Lapis Pondasi Tailing Klas A sesuai spesifikasi gradasi, dibutuhkan sekitar $5 \%$ tailing dari total campuran. Uji coba skala penuh juga telah dilakukan pada ruas Jalan Agimuga, Timika, Kabupaten Mimika, Provinsi Papua, sepanjang 2.740 meter. Dari pelaksanaan uji coba skala penuh ini dapat disimpulkan bahwa tailing dalam campuran lapis pondasi tailing dengan kriteria tertentu 
memenuhi kemampuan sebagai bahan campuran untuk perkerasan jalan.

Jenis pasir yang lainnya yang juga belum termanfaatkan secara optimal sebagai bahan lapis ondasi jalan adalah pasir kuarsa (Iriansyah AS, 2005). Padahal deposit Pasir kuarsa cukup banyak di daerah seperti, Kalimantan Tengah, Sulawesi Tengah, dan Jawa Timur. Seiring dengan teknologi pemakaian aspal emulsi dengan campuran dingin maka telah dilakukan penelitian pasir kuarsa sebagai bahan lapis pondasi dengan campuran aspal emulsi sebagai pengikat (sand base emulsion).

Pasir Sumpur Kudus sebagai Pengganti Agregat Klas A

Kondisi topografi Kabupaten Sawahlunto/Sijunjung bervariasi dan datar bergelombang sampai perbukitan. Beberapa kecamatan berada pada lahan curam dan sangat curam (daerah berbukit), yaitu di Kecamatan Tanjung Gadang, Kecamatan Sijunjung, Kecamatan Sumpur Kudus, dan Kecamatan Lubuak Tarok dengan kematangan antara 15 - $40 \%$ dan lebih besar dan $40 \%$. Hanya sebagian kecil wilayah Kabupaten Sawahlunto/Sijunjung yang termasuk kategori datar

Jenis tanah pada daerah Sumpur Kudus adalah tanah yang terdiri campuran antara pasir dengan sedikit lempung yang mempunyai nilai ikatan antar butiran tanah (kohesi) mendekati nol dan berat jenis yang rendah. Dengan jenis tanah seperti ini, aliran air pada lereng perbukitan yang terbuka, dapat dengan mudah menggerus permukaan lereng, sehingga pada akhirnya tanah yang terbawa air tersebut dapat menutup saluran air dan badan jalan yang ada, seperti terlihat pada gambar berikut.

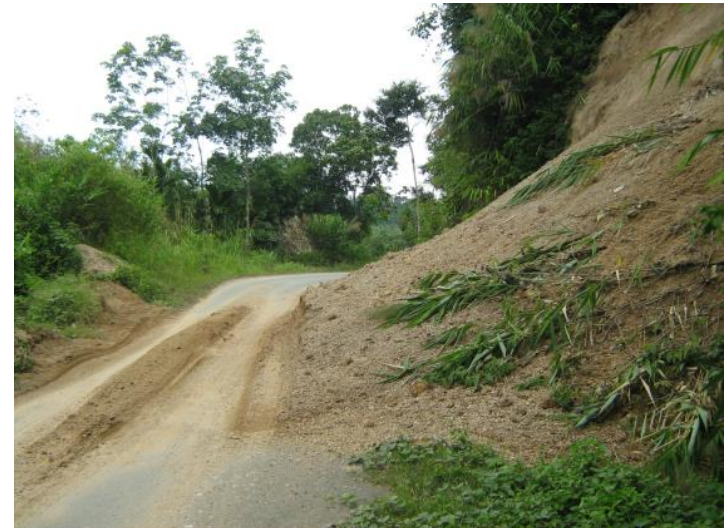

Gambar 1. Pasir Sumpur Kudus yang Longsor

Penelitian yang sudah pernah dilakukan menggunakan tanah daerah Sumpur Kudus ini adalah stabilisasi tanah ini dengan semen. Dari riset yang pernah dilakukan diperoleh hasil gradasi tanah asli ( tanpa campuran semen ) dan klasifikasi tanah Sumpur Kudus ini merupakan tanah non kohesif dan termasuk tanah yang berbutir kasar dengan persentase lempung 3,91\%. ( Enita, dkk 2008 ). Untuk memanfaatkan tumpukan tanah Sumpur Kudus yang berupa pasir berlempung, yang sering menutupi badan jalan, pada penelitian ini digunakan untuk material perkerasan jalan yaitu sebagai pengganti agregat klas $\mathrm{A}$, dimana material klas $A$ yang biasa digunakan adalah pasir sungai dan clay.

\section{Metode Penelitian}

Penelitian yang akan dilaksanakan ini merupakan penelitian skala laboratorium seperti terlihat pada gambar 2 . 


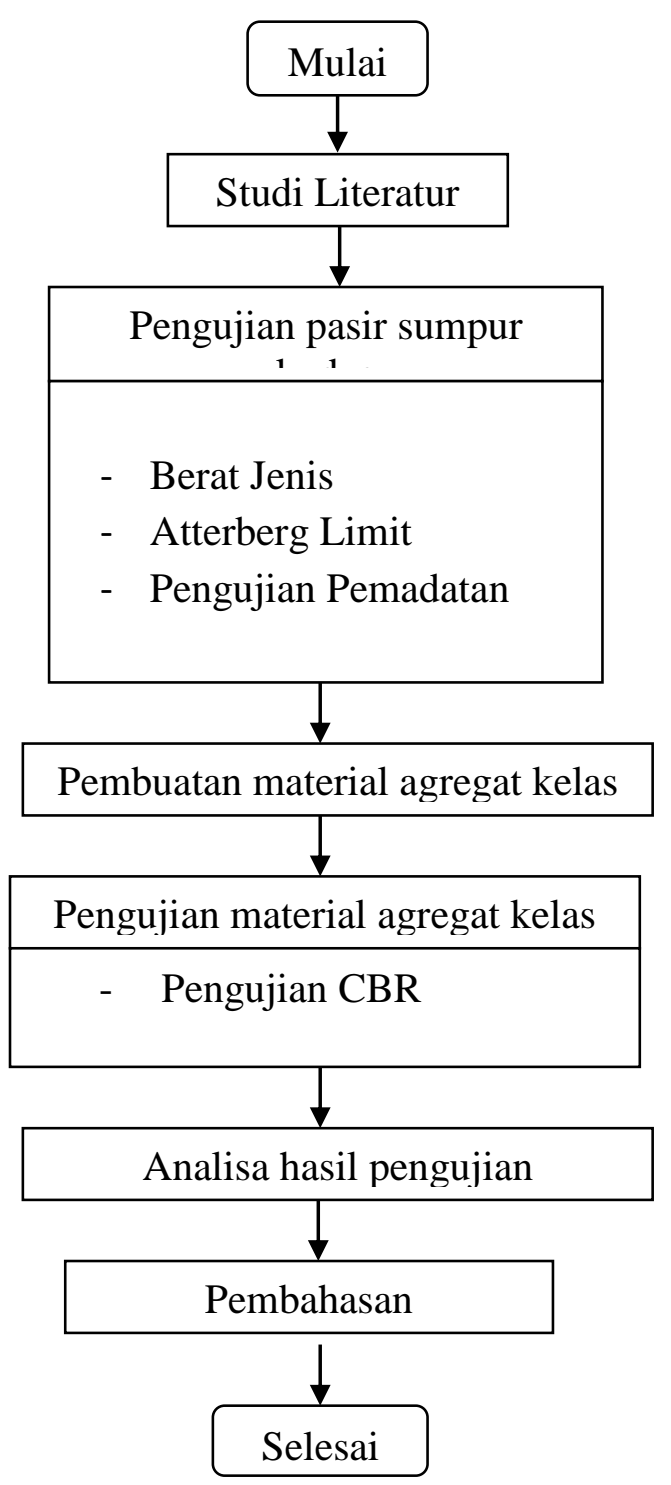

Gambar 2. Bagan alir Penelitian

Metodologi yang digunakan untuk kegiatan penelitian ini adalah dengan melakukan pengujian skala laboratorium. Pengujian yang dilakukan meliputi pengujian terhdaap pasir gunung Sumpur Kudus meliputi pengujian sifat fisis tanah dan pengujian pemadatan. Pengujian terhadap campuran agregat klas $\mathrm{A}$ adalah pengujian CBR.

\section{Lokasi}

Pasir gunung yang akan digunakan sebagai subtitusi agregat halus berasal dari Nagari Sumpur Kudus Kabupaten Sijunjung.
Pengujian dilakukan di laboratorium

Pengujian Tanah Politeknik Negeri Padang.

\section{Perencanaan Campuran Agregat Kelas A}

Perencanaan campuran Agregat Klas A dibuat dari Formula Campuran Rencana yang harus memenuhi ketentuan gradasi yang diberikan pada tabel 1 .

Tabel 1. Gradasi Lapis Pondasi Agregat

\begin{tabular}{|c|c|c|c|}
\hline \multicolumn{2}{|c|}{ Ukuran Ayakan } & \multirow{2}{*}{$\begin{array}{c}\text { Persen } \\
\text { Berat yang } \\
\text { Lolos, \% } \\
\text { Lolos } \\
\text { Agregat } \\
\text { Kelas A }\end{array}$} & \multirow{2}{*}{$\begin{array}{l}\text { Batas } \\
\text { Tengah }\end{array}$} \\
\hline ASTM & $(\mathrm{mm})$ & & \\
\hline $11 / 2 "$ & 37,5 & 100 & 100 \\
\hline 1" & 25,0 & $77-85$ & 81 \\
\hline $3 / 8^{\prime \prime}$ & 9,5 & $44-58$ & 51 \\
\hline No. 4 & 4,75 & $27-44$ & 35,5 \\
\hline No.10 & 2,0 & $17-30$ & 23,5 \\
\hline No. 40 & 0,425 & $7-17$ & 12 \\
\hline No. 200 & 0,075 & $2-8$ & 5 \\
\hline
\end{tabular}

Berdasarkan gradasi agregat diatas, maka proporsi campuran agregat yang akan dicoba dilakukan pencampuran dengan mengambil gradasi rencana berdasakan nilai tengah dari spesifikasi agregat kelas $A$ dengan hasil sebagai berikut:

Agregat kasar : $64,5 \%$

Agregat Halus : $35,5 \%$

Variabel penelitian yaitu persentase pemberian pasir Sumpur Kudus adalah seperti table berikut : 
Tabel 2 Variabel penelitian

\begin{tabular}{|l|l|l|l|}
\hline Sample & $\begin{array}{l}\% \\
\text { agregat } \\
\text { kasar }\end{array}$ & $\begin{array}{l}\% \text { agregat } \\
\text { halus }\end{array}$ & $\begin{array}{l}\% \text { abu } \\
\text { / clay }\end{array}$ \\
\hline I & $64,5 \%$ & $\begin{array}{l}30,5 \% \text { pasir } \\
\text { (tanpa par } \\
\text { Sumpur } \\
\text { Kudus) }\end{array}$ & $5 \%$ \\
\hline II & $64,5 \%$ & $\begin{array}{l}35,5 \% \text { ( pasir } \\
\text { Sumpur } \\
\text { Kudus ) }\end{array}$ & $0 \%$ \\
\hline
\end{tabular}

\section{Pengujian CBR}

Pengujian ini dilakukan berdasarkan SNI 03 1744-1989 dan bertujuan untuk mendapatkan nilai CBR dari campuran lapis pondasi atas agregat klas A. Pengujian CBR dilakukan pada agregat klas A yang tanpa menggunakan pasir Sumpur Kudus dan yang menggunakan pasir Sumpur Kudus

\section{Hasil Dan Pmbahasan}

\section{Pengujian Terhadap Pasir Sumpur Kudus}

- Pengujian Berat Jenis

Hasil pengujian berat jenis pada pasir Sumpur Kudus diperoleh berat jenis Pasir Sumpur Kudus 2,67

\section{- Pengujian Atterber Limit}

Setelah dilakukan pengujian Atterberg limit ( batas cair, batas plastis dan batas susut ) tidak mengeluarkan hasil dan data plastisitas tanah, karena tanah tidak kohesif dan tidak plastis

\section{Pengujian Pemadatan}

Pengujian pemadatan dilakukan sesuai dengan yang disyaratkan ASTM D - 689 untuk Standart Proctor. Dari pengujian pemadatan diperoleh hasil seperti terlihat pada grafik berikut :

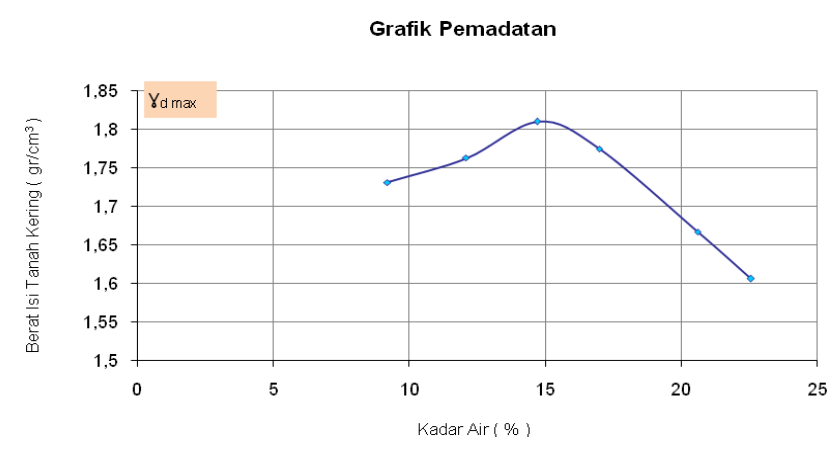

Gambar 3. Grafik Pengujian Pemadatan

Dari grafik di atas diperoleh hasil sebagai berikut :

- $\quad$ Kadar air optimum ( OMC ) $=14,9 \%$

- Berat isi kering maksimum $\left(\gamma_{d} \max .\right)=$ $1,81 \mathrm{gr} / \mathrm{cm}^{3}$

\section{Pengujian Terhadap Agregat Kelas A}

Pengujian $C B R$

Pengujian dilakukan sesuai dengan yang disayaratkan SNI 03 - 1744 - 1989 , yang dilakukan untuk mengetahui nilai CBR tanah dan tanah agregat yang dipadatkan. Pengujian CBR dilakukan terhadap campuran agregat kelas $\mathrm{A}$ tanpa dicampur pasir Sumpur Kudus dan campuran agregat kelas $A$ yang dicampur pasir Sumpur Kudus. Hasil yang diperoleh dapat dilihat pada tabel berikut :

Tabel 4. Hasil Pengujian CBR

\begin{tabular}{|l|c|c|}
\hline \multirow{2}{*}{ Material } & \multicolumn{2}{|c|}{ Nilai CBR ( \% ) } \\
\cline { 2 - 3 } & $\begin{array}{c}\text { Penetrasi } \\
\mathbf{0 , 1} \text { in }\end{array}$ & $\begin{array}{c}\text { Penetrasi } \\
\mathbf{0 , 2} \text { in }\end{array}$ \\
\hline $\begin{array}{l}\text { Campuran } \\
\text { agregat } \\
\text { kelas A } \\
\text { tanpa pasir } \\
\text { Sumpur }\end{array}$ & 23,83 & 40,58 \\
\hline
\end{tabular}




\begin{tabular}{|l|l|l|}
\hline Kudus & & \\
\hline Campuran & 44,92 & 46,20 \\
agregat & & \\
kelas A & & \\
dengan pasir & & \\
Sumpur & & \\
Kudus & & \\
\hline
\end{tabular}

Dari hasil di atas terlihat nilai CBR untuk penetrasi 0,1 in campuran lapis pondasi agregat kelas A tanpa pasir Sumpur Kudus $23,83 \%$, dengan ditambahkan pasir Sumpur Kudus pada campuran lapis pondasi agregat kelas A nilai CBR meningkat menjadi $44,92 \%$. Seperti halnya nilai CBR pada penetrasi 0,1 inc, nilai CBR pada penetrasi 0,2 inc juga mempunyai perilaku yang sama, nilai $C B R$ pada campuran lapis pondasi agregat kelas $\mathrm{A}$ tanpa pasir Sumpur Kudus 40,58\% meningkat menjadi $46,20 \%$ pada campuran lapis pondasi agregat kelas A yang agregat halusnya menggunakan pasir Sumpur Kudus. Dengan menggunakan nilai yang tertinggi, terlihat dengan digunakannya pasir Sumpur Kudus sebagai agregat halus pada campuran lapis pondasi agregat kelas $\mathrm{A}$, nilai CBR laboratorium meningkat $5,62 \%$ yaitu dari 40,58\% menjadi 46,2 \%. Tapi nilai CBR laboratorium yang diperoleh ini masih belum memenuhi standar nilai CBR yang disyaratkan yaitu nilai CBR untuk agregar kelas A minimal $90 \%$.

\section{Kesimpulan}

Pada penelitian penggunaan pasir Sumpur Kudus untuk peningkatan kinerja lapis pondasi agregat kelas A, diperoleh kesimpulan antara lain :
- Dari pengujian Sifat fisik tanah dan pengujian Analisa Saringan, pasir Sumpur Kudus Sijunjung merupakan tanah non kohesif dan termasuk tanah yang berbutir kasar

- Nilai CBR laboratorium meningkat 5,62\% yaitu dari $40,58 \%$ menjadi $46,2 \%$ dengan adanya penggunaan pasir Sumpur Kudus sebagai pengganti agregat halus pada campuran lapis pondasi agregat kelas $\mathrm{A}$

- Dari hasil pengujian terhadap campuran lapis pondasi atas agregat kelas $\mathrm{A}$ tanpa pasir Sumpur Kudus maupun yang menggunakan pasir Sumpur Kudus, nilai CBR yang diperoleh belum memenuhi nilai yang disyaratkan untuk agregat kelas A yaitu minimal $90 \%$

\section{Daftar Pustaka}

Bowless .E, ( 1978 ), "Engineering Properties Of Soil And Their Measure ", Mc GrawHill International Student Edition $2^{\text {nd }}$.

Enita S, ( 2008 ), "Perbaikan Lapisan Tanah

Dasar Perkerasan Jalan Sijunjung Menggunakan Soil Semen", Padang.

Masyhur, ( 2000 ), Modification by Admixtures", Pelatihan Soil Improvement, Bandung

Nono, ( 2009 ), “ Kajian Penggunaan Lapis Pondasi Agregat yang Distabilisasi dengan Semen ", Pusat Litbang Jalan dan Jembatan, Bandung

SNI 03-1744-1989, ( 2005 ), “ Metode Pengujian CBR Laboratorium ", Departemen Pekerjaan Umum.

SNI 03-1742-1989, ( 2005 ), "Metode Pengujian Kepadatan Ringan untuk Tanah“, Departemen Pekerjaan Umum. 
